\title{
Philosophy of Hintuwu and Katuwua as Learning Sources in Teaching Social Science Subject Among Kulawi Indigenous People
}

\author{
Misnah \\ Universitas Tadulako \\ Palu, Indonesia \\ misnahuntad@yahoo.co.id
}

\author{
Nana Supriatna \\ Universitas Pendidikan Indonesia \\ Bandung, Indonesia \\ nanasup@yahoo.com
}

\author{
Iskandar \\ Universitas Tadulako \\ Palu, Indonesia \\ iskandar.ahmad67@yahoo.com
}

\author{
Moh Ali \\ IAIN Central Sulawesi \\ Palu, Central Sulawesi \\ ali_bagus83@yahoo.co.id
}

\begin{abstract}
The purpose of this study is to explore learning values and identify values of the local wisdom of Hintuwu philosophy and katuwua that can be as learning sources of social science subject at school. The main interesting problems in this study are to identify local wisdom values of sintuwu and katuwua philosophy, local culture of indigenous people of Kulawi, and how to implement the values in teaching social science subject at school. The method used was a qualitative descriptive method. The results of this study indicated that the philosophy of hintuwu dan katuwua had precious learning values and they served as a rule of order for indigenous people of Kulawi in Central Sulawesi. Therefore, it is expected that teachers can consider hintuwu and katuwua as learning sources containing ecological values based on principles of respect, solidarity and consensus, and values of environmental conservation such as agriculture that is still maintained and used in everyday life. This study can also provide reference for political decision making, policy, school of thought, curriculum orientation developed by practitioners and educators in teaching social science subject at different schools in Central Sulawesi
\end{abstract}

Keywords-ecological values; local wisdom; Sintuwu and Katuwua, Social Science

\section{INTRODUCTION}

Cultural communities in Indonesia in the context of the local culture in the region having values those become the characteristic of a certain region which serves as guidelines for the community. It is very interesting to explore and develop local wisdom in the context of ecology-based education. Ref. [1] argued that local wisdom is a collection of facts, concepts, beliefs, and perceptions of the community related to the world affairs. Local wisdom is a process of how knowledge is obtained, stored, applied, maintained and inherited. Environmental care as an insolence and achievement to check and to develop efforts to restore the environmental damage. This study discusses ecological crisis which is very important to be investigated since the problem was created by human actions to maintain their existing position in their environment. The importance of maintaining and preserving the environment is to share the responsibility of society who live on earth. Positions that local wisdom is a measure of culture. Local wisdom is an element of traditional culture that deeply rooted in human life and community that related to human resources, culture, economic, security, and laws. Local wisdom can be viewed as a tradition that related to farming activities, livestock, building a house, etc.

Ref. [2] proposed that the nature of knowledge, beliefs in customs based on the experience of human life, ecologically is a heritage which for generations is a tradition in the life of local communities. The environmental wisdom of indigenous/local is essentially derived from the value systems and religion professed by the community. Its inherent nature is to give guidance to people to behave in harmony and tune with the rhythm of the universe to create a balance relations between humans and nature. Man in survival would be associated with the surrounding natural environment, but the fact that recently occurred the exploitation of the environment causes much loss of human life.

The recent environmental problems relate to the lack of public awareness of the environment. The term consciousness derived from the word "conscious" means be aware of, feel, know and understand. Ref. [3] stated that human consciousness is an important element in understanding the reality and in how to act or respond to the realities of life. Human beings' awareness is selfawareness which can be developed through a process of learning and habituation. The values developed in education is the character value. Puskur Development Team identifies eighteen (18) point of values, and one of them is the value environmental concerns. In 
principle, the development of culture and character is not included as a subject but it is integrated into the subjects, envy and cultural development of the school. Therefore, teachers and schools need to integrate these values which are developed into values-based education, character education.

People in the village of Toro, one of the districts in Sigi regency, Central Sulawesi are a society who still maintain ecological based local values, and still protecting the natural environment. Toro villagers maintain the values of local wisdom relating to the philosophy of life that serve as guidelines for life in the village. The philosophy is known as Sintuwua and Katuwua. The values of local wisdom containing in the philosophy of Sintuwu and Katuwua can be used as a source of learning social studies in schools. Philosophy of Sintuwu and Katuwua is a heritage passed down from generation to generation. Inheritance and instilment of the ecological values through local culture Sintuwu and Katuwua for Kulawi indigenous people in Sigi Regency is an effort to pass on the noble values to maintain the balance of the ecological system. The ecological crisis occurs as a result of human activity. Puskur Development Team defines environmental concern as an attitude and action to prevent natural environmental damage and to develop efforts to restore the destruction.

One of the outstanding issues is the establishment of the Joint Memorandum between Ministry of Education and Culture with the Ministry of Environment No. 0142 / U / 1996 and No. Kep: 89 / MENLH / 5/1996 on Coaching and Development Environmental Education, dated May 21, 1996. Accordingly, the Directorate General of Primary and Secondary Education Department of Education and Culture encourage the development and strengthening the implementation of environmental education in schools through teacher training, among others, the promotion of environmental devotion month, preparation of Guidelines for implementation of Population and Environment Education (PKLH) for teachers of primary school, Junior High School, Senior High School and Vocational School, and the harmony school program.

Local culture context in the region will be integrated into environmental education based learning which is one of the contextual themes will be integrated into the subjects. Local wisdom is one of the approaches used in the class and it will be a source of learning. Localities in ecology-based Social Science learning becomes highly contextual material to assess the local cultural issues. This learning will determine how learners' knowledge of the social environment will be applied in their public life, therefore, students should be able to connect between the what happened in past, what is happening now, and what will happen in the future. These values will enrich the novel studies on Social Science subject learning.

Regulation of the Republic of Indonesia Number 4 the year 1982 on the Principles of Environmental Management defines the environment as a unity with all things, power, the state of living creatures including humans and their behavior that affect the sustainability of the livelihoods and well-being of humans and other beings. Environmental issues are closely connected with ecological problems. Ref. [4] proposes ecology as the study of the relationships between living things as a unity with its environment, wherein include the physical, biological, socio-economic and political factors. Ref. [5] argues that (environmental science) is the study of the living environment, and environmental science is an applied biological science, and ecology is a fundamental science. Ref. [6] defines ecology as the science of mutual relations between living beings with their environment.

The novel and integration of the values of the environment are the main issues in learning social studies, it is because of the environment is the place for students to learn. Problems occurred in the community will shape the character of the students and prepare them in the public life as citizens for the next generation. The utilization of local wisdom Sintuwu and katuwua as the source of learning in social studies is relevant to as described by [7] that Social Science originates from practical daily lives, thus the learning of social science focuses on the society. In line with this, [8] describes that local culture in today's society sourced from public and tradition can be explored and used as ecological based learning. Learning of social science subject should be addressed properly since most of the teachers focus on the textbooks and students' worksheets. However, this kind of learning process trigger problems for the students, as they do not know and do understand the problems related to ecological wisdom based on values in the real life. Therefore, it needs to revitalize the learning approach in schools in Central Sulawesi in particular.

\section{METHODS}

This research employed a descriptive qualitative method. Descriptive research is a type of research that provides a picture or description of a situation as clearly as possible without treating the subject of the research. In general, the descriptive study uses the survey as a method of data collection [9-11].

Descriptive qualitative research method [9], [10] is a research that produced the descriptive data in the form of writing about people and their behaviors that can be observed. The qualitative descriptive method is a type of research that produced the raw data or still in the form of words which is then analyzed into an accurate data which is not manipulated and at the end, obtain the result by concluding which consistent with the objectives of the study.

\section{A. Data source}

Data on this study are primary data in the form of words obtaining from informants and local utterances. While secondary data was obtained from oral culture notutura (oral history) and the key informants were indigenous leaders and community leaders.

\section{B. Technique of Data Collection}

Data from this study were obtained from: 
- Interview techniques; Researchers interviewed the informant or source people to study the ecology-based local wisdom.

- Documentation technique; the researchers took pictures of objects related to the research that can be used as evidence of the results of research.

- Data Evaluation; test the data obtained from the key informants employing additional informants who are living in the area of research.

\section{Technique of Data Analysis}

Once the data collected, then it needed to transcribe the interview data and then interpreted the transcript interview which was in the local language to the Indonesian Language in relation to ecology-based local wisdom and then analyzed the interpreted interview data.

\section{RESULTS AND DISCUSSIONS}

\section{A. Description of Kulawi Society}

Toro community is a traditional farming community who use the forest as a source of their life. The residential area of Toro community is surrounded by mountains as the source of their livelihood. Toro is one of the villages (Ngata) locates in Lore Lindu National Park, Central Sulawesi Palu. Administratively, the village is incorporated in the District of Kulawi, Sigi Regency, Central Sulawesi. The village has an area of approximately 22,950 ha at an altitude of 700 meters above sea level with cooler weather since it is surrounded by mountains (Statistical data, Sigi District, 2015).

Ethnic majority inhabiting Toro Village (Ngata) are Moma ethnic group as indigenous ethnic, and Ampi and Uma ethnic groups as Immigrants. Ethnic diversity is a unique identity that creates Boya-boya (Hamlet). Despite the community came from different ethnics, they are bound together in a relationship that has a kinship, mutual respects, peaceful live, mutual help and mutual cooperation.

Toro community is traditional farmers inherited from their ancestor. They use the forest as their source of livelihood. They use and process the forest product to meet their necessities. The way of using the forest as the main source of livelihood will be decisive to the needs of clothing, food, and shelter. Ways of processing the forest are: gardening (Pobonea); planting rice (pae); planting corn (mariha); planting vegetable (uta-uta). They are planted under huge and dense trees located in the mountainous area where coffee trees, rattans (bamboos), or aromatic foliage which can be used as pakuli (traditional medicine) and also palm (tule) planted by the communities (Interviewed to Sologi, at 10 a.m on November 12, 2016). Toro communities who inhabit Kulawi Sub-district exploit the forest as a source of livelihood to meet their needs economically. Toro community holds the philosophy that forest should be preserved since it gives benefits to people who live in the vicinity.

\section{B. Philosophy of Hituwua and Hituwua the Community NgataToro}

The people in the village of Toro have high cultural values, which are still maintained from the time of the ancestors who then passed down through the generations. Social life institution regulated by customary institutions or customary rules which still survive today, a long evolutionary history between communities and their environment. Evolussi formed is characteristic of the culture that is synonymous with Ecological stability. Characteristic of this culture is still reflected in the ecological stability of social and cultural institutions that use, maintain and preserve resources. Local wisdom in the form of forest maintenance is a very important value and proud today as it already affected by modernization, globalization, capitalism, and consumerism. It is an honor that is invaluable that we can still find communities that Toro Society who cares nature in the form of maintenance of ecological culture in social institutions Toro.

The main basis of society to maintain or keep the ecology and natural resources because of the philosophy they hold and believe. Toro community has two philosophies as the philosophy of life those are Hintuwu and Katuwua. Hintuwu set relationship in public life including the principles of respect, solidarity, and consensus. While Katuwua set the relationship between humans and the environment which is seen as a philosophical wisdom attitude and harmony with nature.

Meaning value of the philosophy or way of life which inherited from generation to generation is a social relation which is a normative reference that has to be commonly understood, so the people can do the right things to nature and fellow human beings. These values are incorporated into the rules of customary law which is the guideline of Toro community. This law must be adhered by all members of Toro community (interviewed with Albert on November 15, 2016).

According to Salogi (interviewed in November 2016), hereditarily, society Toro equip life their lives with the philosophy of natural resources management which is known as local wisdom in taking care nature (Mopahilolonga Katuwua). Society of Toro has opinion that people should keep the three elements, i.e human (tauna), animals (pinatuwua) and herbs (tinuda). At the moment, Toro society believes that this philosophy is the principle of such ecological diversity (nadea ngaa nengila), interdependence (none harumaka), networks (hampobagoa hampodohea) and the chain food (mome-koni koni)

Based on the explanation above, Toro society has very high values and form a pattern of life in maintaining ecological stability which is reflected in the pattern form of natural resources utilization system based on the philosophy of Hintuwua and Katuwua. These two philosophies are the cultural values based on 
a local culture that is heredity from generation to generation. In principle, the two philosophies view that life on earth has a reciprocal relationship, grow and reproduce, and mutual support. Toro community has the ecological intelligence to preserve cultural and ecological environment supported by the knowledge inherited from generation to generation. Therefore, the sustainability of nature can be maintained, and all living things including human can coexist.

This is affirmed by [12] that community is said to have ecological intelligence is a society that understands that every action and behavior does not only impact on him but also impacts on others and also have an impact on the natural environment where he lives. The intelligence is an understanding of awareness of the importance of protecting, maintaining, and conserving nature and establishing a good relationship with the living things on earth. Harmony action with nature is one of the ways to preserve the natural environment. Ecological contents should be able to present the actual reality where the students live. By presenting the real environmental problems occur in the community, then the students will have a better understanding of the related studies. They are also able to respond to the natural phenomena in their surroundings, as a part of their awareness and responsibility as a member of the community. It is important to set good citizens who are knowledgeable and skillful and have noble values and wellbehaved to actively participate in the society [13], [14].

A similar opinion expressed by Jacob in environmental studies related to the culture of the Toro villagers in the utilization of the existing land. Utilization of community-owned land is set and determined by indigenous institutions of Toro that hold the philosophy of Hintuwu and katuwua which is retained by the Toro community. Both philosophies have established a culture and set a characteristic in maintaining ecological stability as follows

1. If Land and all natural resources would be privately owned, then the prospective owner should have the right of ownership over the cleared land. Then the prospective owner will be able to manage the forest or land which will be used as plantation or agricultural lands (pampa)

2. The Basis of other private ownership is the result of purchase (raiadai conferral from but the landowners will not have the freedom to manage forests or land. However, the activities and the utilization of the forest should not conflict with customary law in the society and will be set out in the joint deliberation of indigenous institutions and governments in the village of Toro

3. The authority of indigenous institutions is to organize the relationship between one Ngata (village) with the other villages (hintuwu Ngata), set solutions when there are people violate the preservation of the custom environment in Toro Village.

4. The role of Totua Ngata (indigenous leader) is to supervise the customary rules agreed in polibu (consultation) to resolve the problems relating to the preservation of protected forest, such as the ban on the harvesting of rattan, yellow bamboo, pandanus palm forest. Ban on forest clearings if it is found out that there is a tree resin, ban on logging when the trees are the source of food for the birds in the forest.

\section{B. Learning Strategies of ecology-based social science Subject}

Implementation of ecological values on the local culture of the community of Toro in Kulawi Sub-district in learning social science subject can be done by identifying ecology based local wisdom which relevant to learning material of social science subject. According to [15] to get ecological competence in a social science subject, the set competence should be in line with the characteristics of the social science subject. Basically, social science has environmental education materials and contents. In social science, there are four variables that should be developed: (a) people, places, and the environment; (b) time, sustainability and change, (c) social and cultural systems, (d) economic behavior and well-being. All the learning material of social science can use the community both physical and social aspects as the primary source of learning because the nature of social science learning is learning the interaction of humans with others in the context of space and time which cannot be separated from their environment. In particular, environmental content can be inserted in the learning materials of social science subject which involving four variables as aforementioned.

There are some cases need to be integrated into the learning strategy of social science subject involving environmental issues that exist in Toro village, such as others: ecological content in the learning of social science subject should be derived from local issues and from environmental issues found in everyday life. Then, use environmental issues occur at the national and global level. Hence, students can get the insight on the environmental issues in other geographical areas. Understanding the environmental issues and problems can be developed through learning the integration of social science subject with other subjects using an interdisciplinary, multidisciplinary, and cross-disciplinary approach which may generate a new approach and holistic understanding and create a balanced perspective. Environmental issues and problems are investigated by describing the problems, outlined the problems, identify causes and effects, and find solutions to the problems in a variety of perspectives and disciplines. In learning the environmental issues and problems, students are encouraged to relate their environmental awareness, their knowledge, and skills to solve the problems and justify the values related to the environment. Students' critical thinking skill is needed to be developed so they are able to solve the problems and able to implement the solution. One of the critical thinking needs to be developed is discovery skill. By having this skill, the students are able to find out the causes of the environmental problem and its complexity. Issues and environmental problems are developed to sharpen critical thinking skills, find (discover) the symptoms and causes of environmental problems, emphasize the complexity of environmental problems. This ability is very 
important to think critically about the skills to solve problems and a willingness to act and implementing it.

\section{CONCLUSION}

Local wisdom-based learning using Hituwua and Katuwua philosophies concern on environmental problems in the study of social science. Learning process teaches the students to conduct field investigations, analyze the real problems in society, challenging students to be active and creative, cultivate curiosity, capable of critical thinking, solution-based, and participatory. Utilization of ecological based local wisdom constructs knowledge of students as a basic learning. In this context, students develop a new understanding through the construction process of students 'prior knowledge actively and connect with the environment in the students' surrounding, so that develops students' knowledge construction more actively. Through direct learning in society, it can bring real-world situations which can encourage students to connect with their knowledge and its application in their lives. Students develop an understanding based on interpretation of themselves and their surroundings. Thus, think out a new and profound knowledge, and complex in accordance with the level of its development.

\section{REFERENCES}

[1] Al Wasilah,Chaedar.A. dkk. Etnopedagogi landman Prahek Pendidikan dan Pendidikan Guru. Bandung: PT Kiblat Buku Utama. 2009. [1]

[2] Keraf, S. Etika Lingkungan. Jakarta: Penerbit Buku Kompas. 2002. [2]

[3] Kamus Besar Bahasa Indonesia [3]

[4] Supardi. K. Dkk. Potret Professionalisms Guru dalam Membangun Karakter Bangsa. Bandung. Li PI Press. 2010. [4]

[5] Manik. Pengelolaan Lingkungan Hidup. Jakarta: Jambatan. 2009 [5]

[6] Soemarwoto, O. Ekologi Lingkungan Hidup dan Pembangunan. Jakarta: PT Jambatan. 1994. [6]

[7] Roswidyatmoko Dwihatmojo. Staf Pusat Tata dan Ruang Atlas Badan Informasi Geospasial(BIG). [7]

[8] Kahn, R. Critical Pedagogy, Ecoliteracy, \& Planetary Crisis, The Ecopedagogy Movement, New York: Peter Lang. 2010.[8]

[9] Creswell. Educational Research. Boston: Pearson. 2012. [9]

[10] Heppner. Research Design in Counseling. US: Thomson. 2008. [10]

[11] Kountur. Metode Penelitian untuk Skripsi dan tesis. Jakarta. PPM. 2005. [11]

[12] Supriatna,N.2016.Ecopedagogy.Membangun Kecerdasan Ekolois dalam pembelajaran IPS.Remaja Rosdakarya.Bandung [12]

[13] Jarolimek, J \& Parker, W.C (1993). Social Studies in Elementary School. (9th ed.). New York: Macmillan Publishing Company. [13]

[14] Sumaatmadja, N. Perspektif Studi Sosial. Bandung: Alumni. 1980. [14]

[15] Misnah. Ethnopedagogy The Proceeding of internasional.Lambung Mangkurat.Unlam press.(2015). [15]

Data Informan

1. Nama : Yakup Katib

Umur : 60 Tahun

Agama : Kristen

Jabatan : Ketua Adat

2. Nama : Frangki
Umu ; 60 Tahun

Agama : KristenAdat

Jabatan : Anggota Adat

3. Nama : Albert

Umur : 58 Tahun

Agama : Kristen

Jabatan : Anggota adat

4. Nama : Salogi

Umur :63 Tahun

Agama : Kristen

Jabatan : Anggota Adat 